\title{
Meningkatkan Kemampuan Mengapresiasi Unsur Teks Cerita Fantasi Dengan Metode Numbered Head Together (NHT) Pada Kelas VII A SMP Raj Yamuna Tahun Pelajaran 2017/2018
}

\author{
Ririn Dwi Lestari \\ SMP N 2 Abiansemal \\ ririnputri654@gmail.com \\ Ni Wayan Murni \\ SMP N 2 Abiansemal \\ murniwayan632@gmail.com
}

I Ketut Suar Adnyana

Program Studi Pendidikan Bahasa Indonesia dan Daerah, Fakultas Keguruan dan Ilmu Pendidikan, Universitas Dwijendra

suara6382@gmail.com

\begin{abstract}
Abstrak
Apresiasi dapat dilakukan dengan membaca cerita fantasi dan merangkum berdasarkan unsur yang terdapat dalam teks cerita fantasi. Unsur cerita dibagi menjadi dua yaitu unsur intrinsik dan unsur ekstrinsik. Oleh karena itu penelitian tentang "Meningkatkan Kemampuan Mengapresiasi Unsur Teks Cerita Fantasi dengan Metode Numbered Head Together (NHT) pada kelas VII SMP Raj Yamuna tahun pelajaran 2017/2018”. Penelitian ini menjadi pertimbangan dalam meningkatan kemampuan peserta didik dalam mengapresiasi teks cerita fantasi. Penelitian ini dilakukan karena kurangnya minat siswa dalam mengapresiasi cerita. Dalam penelitian ini permasalahannya adalah metode NHT dapat meningkatkan kemampuan siswa dan respon siswa setelah menggunakan metode NHT. Teori yang digunakan adalah teori teks cerita fantasi. Metode yang digunakan adalah metode observasi dan metode dokumentasi. Metode observasi dilakukan dengan cara mengamati secara langsung proses pembelajaran. Sedangkan metode dokumentasi sebagai bahan pendukung. Teknik yang digunakan adalah teknik kuesioner yang berfungsi sebagai penilaian respon dalam proses pembelajaran. Berdasarkan hasil analisis dapat disimpulkan dalam penerapan metode NHT pada saat proses pembelajaran dapat meningkatkan hasil belajar peserta didik. Penerapan metode NHT dapat dijadikan alternatif dalam mengatasi kejenuhan peserta didik dalam proses pembelajaran. Dengan metode NHT peserta didik dapat berkomunikasi dan saling bekerja sama dengan teman lainnya.

Kata kunci : Mengapresiasi Teks, Unsur Teks Cerita Fantasi, dan Metode NHT
\end{abstract}

\begin{abstract}
Appreciation can be done by reading fantasy stories and summarizing based on the elements contained in the fantasy story text. The story element is divided into two, namely the intrinsic and extrinsic elements. Therefore, research on "Meningkatkan Kemampuan Mengapresiasi Unsur Teks Cerita Fantasi dengan Metode Numbered Head Together (NHT) pada kelas VII A SMP Raj Yamuna tahun pelajaran 2017/2018“. This research is a consideration in improving the ability of students to appreciate fantasy story texts. This research was conducted because of the lack of students' interest in appreciating stories. In this study the problem is that the NHT method can improve students' abilities and student responses after using the NHT method. The theory used is the theory of text fantasy stories. The method used is the observation method and documentation method. The observation method is done by observing the learning process directly. While the documentation method is supporting material. The technique used is a questionnaire technique that functions as a response assessment in the learning process. Based on the results of the analysis can be concluded in the application of the NHT method during the learning process can improve student learning outcomes. The application of the NHT method can be used as an alternative in overcoming the saturation of students in the learning process. With the NHT method students can communicate and work together with other friends.
\end{abstract}

Keyword: Appreciate Text, Fantasy Story Text Elements, and NHT Method. 


\section{PENDAHULUAN}

Setiap jenis cerita dapat diapresiasikan untuk menghargai dan menilai sebuah karya sastra. Dalam mengapresiasikan sebuah karya sastra terlebih dahulu harus mengenal, memahami, dan menghayati suatu karya sastra tersebut. Pemahaman tersebut sangat bergantung pada kemampuan pembaca dalam memahami konteks pembicaraan yang melatari karya sastra (Suryani, dan Adnyana, 2021:152) Hal itu sangat berbeda dengan dialog yang dilakukansehari-hari. Karya sastra dapat dikenal atau dipahami melalui unsur-unsur yang membangunnya atau disebut dengan unsur intrinsik. Yang dimaksud unsurunsur intrinsik, yaitu tema, plot/alur, tokoh, penokohan, latar, seting, amanat/pesan, sudut pandang, dan gaya bahasa. Selain dari unsur intrinsik dan teks seni berbahasa, juga dapat diapresiasi dengan menelaah penggunaan atau pilihan kata serta istilah yang terdapat dalam teks tersebut.

$\begin{array}{rrr}\text { Banyak } & \text { yang } & \text { salah } \\ \text { mengartikan } & \text { bagaimana }\end{array}$ mengapresiasikan suatu karya sastra. Apresiasi sastra adalah kegiatan mengakrabi, menafsirkan kualitas, dan menilai karya sastra melalui proses pengenalan, pemahaman, penghayatan, penikmatan, dan penerapan terhadap pengalaman hidup yang terkandung dalam karya sastra tersebut. Permasalahannya adalah minat seseorang untuk mengetahui apa itu sastra dan bagaimana memahami serta menghayati isi sebuah karya sastra. Salah satu jenis karya sastra adalah cerita fantasi. Menurut Kamus Besar Bahasa Indonesia (dalam Artati dan Darmawati, 2016:41) cerita adalah tuturan yang membentangkan proses terjadinya suatu hal (peristiwa atau kejadian). Fantasi adalah gambaran (bayangan) dalam angan-angan; khayalan; atau daya untuk menciptakan sesuatu dalam angan-angan. Jadi cerita fantasi adalah gambaran peristiwa sesuai urutan waktu berdasarkan daya pikir, daya khayal yang dituangkan dalam bentuk cerita. Rangkaian peristiwa dalam cerita digerakkan dengan hukum sebab-akibat. Meskipun teks ini termasuk dalam karangan fiksi namun cerita ini umumnya menceritakan perkembangan kejadian atau peristiwa yang berawal dari prolog hingga epilog yang telah melalui beberapa tahapan seperti awal konflik, puncak permasalahan dan penyelesaian. Cerita berkembang dari tahap pengenalan (apa, siapa, dan dimana kejadian terjadi) timbulnya pertentangan, dan penyelesaian/akhir cerita. Jenis cerita fantasi sendiri terdiri dari dua yaitu fantasi aktif dan fantasi pasif. Fantasi aktif adalah fantasi yang dikendalikan oleh pikiran dan kemauan. Di mana fantasi aktif yang laangsung dilakukan seperti seorang pelukis yang sedang melukis. Di sini seorang pelukis yang sedang berkhayal atau berimajinasi dan langsung meluapkannya pada 
sebuah lukisan (Santika, 2017).

Sedangkan fantasi pasif adalah fantasi yang tidak dikendalikan oleh pikiran. Seolah-olah orang yang berfantasi hanya pasif sebagai wadah tanggapantanggapan seperti halnya melamun.

Untuk mempermudah dan menumbuhkan minat pembaca dalam membaca cerita fantasi adalah dengan cara menganalisis cerita tersebut berdasarkan pendekatan struktural (Berta \& Swarniti, 2020). Pendekatan struktural adalah menganalisis berdasarkan unsur-unsur yang terdapat dalam teks cerita fantasi. Unsur tersebut adalah unsur intrinsik dan unsur ekstrinsik yang terkandung dalam cerita tersebut. Dalam teks cerita fantasi memiliki unsur yang terkandung di dalamnya (Swarniti, 2020). Unsur tersebut antara lain unsur intrinsik dan unsur ekstrinsik. Unsur intrinsik adalah unsur-unsur yang membangun karya sastra itu sendiri. Unsur-unsur inilah yang menyebabkan suatu teks hadir sebagai teks sastra (Lede \& Swarniti, 2020). Unsur intrinsik cerita fantasi terdiri dari tema, latar, penokohan, sudut pandang dan amanat. Sedangkan unsur ekstrinsik adalah unsur-unsur yang berada diluar teks sastra itu, tetapi secara tidak langsung memengaruhi bangun atau sistem organisme teks sastra. Unsur ekstrinsik cerita fantasi antara lain bahasa, latar belakang pengarang dan nilai-nilai yang terkandung dalam cerita fantasi. Sehingga pembaca dapat mengapresiasikan sastra tersebut dengan sederhana mungkin dan membuat pembaca semakin tertarik lagi untuk mengapresiasikan sastra yang lainnya.

$$
\text { Dalam proses pembelajaran }
$$
peserta didik memiliki kemampuan yang kurang baik dalam menganalisis unsur-unsur yang berkaitan dengan teks cerita fantasi. Di mana peserta didik secara langsung menganalisisnya dalam sebuah cerita. Jika diamati peserta didik mengalami kesulitan pada saat menganalisis cerita karena dalam sebuah cerita per kalimat akan memiliki beragam pengertian dan makna. Jadi setiap peserta didik akan memiliki jawaban yang berbeda antar peserta didik lainnya. Proses pembelajaran berkelompok untuk menganalisis cerita fantasi dapat menggunakan metode Numbered Head Together (NHT). Menurut Manurung, 2013 (Krisno, 2016:115) Metode pembelajaran Numbered Head Together (NHT) merupakan salah satu model pembelajaran kooperatif (Santika, 2021a). Pada metode ini peserta didik menempati posisi yang sangat dominan dalam proses pembelajaran dengan ciri khasnya adalah pendidik hanya menunjuk seorang peserta didik yang mewakili kelompoknya. Dalam pembelajaran NHT setiap peserta didik dalam kelompok merasa bertanggung jawab terhadap hasil kerja kelompoknya (Santika, 2018). Di mana peserta didik diharapkan dapat bekerja sama dengan teman yang lain untuk menyelesaikan permasalahan yang terdapat dalam sebuah teks cerita fantasi yang diberikan 
oleh pendidik.

\section{Metode Numbered Head}

Together memiliki kelebihan dan kekurang dalam proses pembelajaran. Kelebihan metode ini adalah dapat meningkatkan prestasi belajar peserta didik, memperdalam pemahaman peserta didik, melatih tanggung jawab peserta didik, mengembangkan rasa ingin tahu peserta didik, meningkatkan rasa percaya diri peserta didik dan mengembangkan rasa saling memiliki dan kerjasama serta setiap peserta didik termotivasi untuk menguasai materi.

Kekurangan dalam metode ini yakni, ada peserta didik yang takut terintimidasi bila memberi nilai jelek kepada anggotanya. Ada peserta didik yang mengambil jalan pintas dengan meminta tolong pada temannya untuk mencari jawaban. Dan apabila pada satu nomor kurang maximal mengerjakan tugasnya, tentu saja mempengaruhi pekerjaan pemilik tugas lain pada nomor selanjutnya (Imas, 2017: 30-31).

$$
\text { Dengan demikian }
$$

mengapresiasikan sastra dapat dilakukan oleh peserta didik dalam proses pembelajaran dengan metode Numbered Head Together (NHT) di mana peserta didik memiliki kesempatan untuk berargumentasi dengan teman sekelompoknya dan menyimpulkan hasil diskusi mereka. Sehingga dari hasil diskusi tersebut peserta didik dapat menceritakan kembali berdasarkan unsur-unsur yang terkandung dalam teks cerita fantasi. Hal tersebut adalah salah satu cara mengapresiasikan sastra dengan sederhana dan akan membuat pembaca semakin tertarik untuk mengapresiasikan karya sastra lainnya.

Batasan masalah yang harus dicapai adalah apakah metode Numbered Head Together (NHT) dapat meningkatkan kemampuan mengapresiasi unsur teks cerita fantasi dan bagaimana respon peserta didik dalam proses pembelajaran jika menggunakan metode Numbered Head Together (NHT)? Dengan batasan masalah tersebut diharapkan peserta didik mampu memahami unsur yang terdapat dalam cerita fantasi tersebut dan dapat mengapresiasikan karya sastra dengan baik.

Secara teoretis, penelitian ini dapat dijadikan ancangan dalam pengembangan teori struktural dalam proses pembelajaran. Selain itu dapat membuktikan bahwa kajian struktural masih relevan dikaji untuk menentukan struktural sebuah karya sastra. Penelitian ini memiliki manfaat yang dapat dilihat dari segi guru atau pendidik, siswa dan dalam lingkungan masyarakat. Manfaat bagi guru adalah dengan menggunakan metode Numbered Head Together (NHT) seorang pendidik dapat mengevaluasi atau menilai sejauh mana kemampuan peserta didik dalam memahami pembelajaran teks cerita fantasi dengan berdiskusi menyampaikan argumentasi kepada teman lain sehingga melatih pemikiran seorang peserta didik. Manfaat bagi siswa adalah peserta didik 
dapat meningkatkan kemampuan

berfikir untuk menyelesaikan dan memecahkan permasalahan yang dijadikan media diskusi. Manfaat bagi masyarakat adalah dengan menggunakan metode pembelajaran Numbered Head Together (NHT) dapat melatih peserta didik untuk mengemukakan pendapat atau argumentasi mereka pada saat dilingkungan masyarakat sehingga siswa dapat berkomunikasi dengan baik di lingkungan masyarakat.

Penelitian ini juga dibantu dengan beberapa referensi yang dikaji dalam kajian pustaka. Kajian pustaka yang digunakan dalam penelitian ini bertujuan sebagai bahan acuan landasan teori yang digunakan dalam mengkaji permasalahan sesuai dengan batasan masalah yang dipaparkan sebelumnya. Dalam kajian ini di bantu dengan beberapa referensi berupa buku, jurnal, skripsi dan internet. Berikut beberapa referensi yang digunakan sebagai acuan dalam melakukan penelitian :

(a) Duratun Nafisah yang berjudul Karakteristik Cerita Fantasi Anak Periode 2000-2010 pada tahun 2012. (b) $\mathrm{Hj}$. Neneng Rahayu yang berjudul Penggunaan Komik sebagai Media Pembelajaran untuk Meningkatkan Kemampuan Mengapresiasikan Cerita Fantasi pada peserta didik kelas VII A SMP Negeri 3 Subang tahun pelajaran 2016-2017. (c) Najmi Fajria yang berjudul Pelaksanaan Pembelajaran Teks Cerita Fantasi di kelas VII F SMP Negeri 8 Yogyakarta. (d) Elin Nofia,dkk yang berjudul Tokoh dan Penokohan dalam Teks Cerita Fantasi karya siswa kelas VII SMP Negeri 1 Payakumbuh. (e) Finny Rizkiah,dkk yang berjudul Struktur dan Kebahasaan Teks Cerita Fantasi karya siswa kelas VII SMP Pembangunan Laboratorium.

Selain referensi yang digunakan penelitian ini perlu ditinjau dari segi kurikulum 2013 (Santika, 2021c). Kurikulum 2013 sendiri merupakan sebuah kurikulum yang mengutamakan pada pemahaman, skill, dan pendidikan berkarakter, dimana siswa dituntut untuk paham atas materi, aktif dalam proses berdiskusi dan presentasi serta memiliki sopan santun dan sikap disiplin yang tinggi. Kurikulum ini pun mempunyai kelemahan dan keunggulan. Kurikulum 2013 memiliki empat aspek penilaian, yaitu aspek keagamaan, aspek pengetahuan, aspek keterampilan, aspek sikap dan perilaku.

Kompetensi dasar dalam aspek pengetahuan adalah Mengidentifikasi unsur-unsur cerita fantasi yang dibaca dan didengar. Melalui kompetensi tersebut indikator yang dapat dicapai dalam proses pembelajaran adalah sebagai berikut; Peserta didik dapat membedakan antara cerita imajinasi dan cerita fantasi, peserta didik dapat menjelaskan ciri umum cerita fantasi yang dibaca atau didengar, peserta didik dapat mengidentifikasi jenis cerita fantasi berdasarkan latar dan kesesuaian dalam kehidupan nyata. Peserta didik 
dapat menjelaskan unsur-unsur yang terdapat dalam cerita fantasi intrinsik maupun ekstrinsik. Berdasarkan batasan masalah pada penulisan ini adalah mengapresiasikan unsur cerita fantasi. Dalam hal ini berpengaruh dalam hasil penelitian yang dilakukan. Dengan ini penulis dapat mengamati sejauh mana kemampuan peserta didik dalam mengapresiasikan dan memahami materi pembelajaran yang disampaikan oleh pendidik dengan menggunakan metode pembelajaran Numbered Head Together (NHT).

Selanjutnya kompetensi dasar yang dapat dinilai langsung adalah aspek keterampilan yaitu Menceritakan kembali isi cerita fantasi yang dibaca dan didengar. Berdasarkan kompetensi dasar tersebut indikator yang akan dicapai oleh peserta didik adalah peserta didik dapat menyimpulkan cerita fantasi mengambil pokok atau gagasan ide yang terpenting. Peserta didik dapat menceritakan kembali isi cerita fantasi yang dibaca atau didengar secara lisan maupun tulisan. Jika dikaitkan dengan hasil penelitian diharapkan aspek keterampilan ini dapat dilakukan dengan baik oleh peserta didik. Pada aspek ini peserta didik dapat menghasilkan sebuah produk nyata yang berkaitan dengan apresiasi sebuah karya sastra. Di mana dalam hal ini peserta didik harus mampu menceritakan kembali hasil mengidentifikasi sebuah cerita fantasi berdasarkan unsur-unsur teks cerita fantasi, baik unsur intrinsik maupun unsur ekstrinsik yang harus peserta didik simpulkan sehingga menjadi sebuah ringkasan cerita dari perwujudan atau cara mengapresiasikan cerita fantasi dengan sederhana.

\section{METODE}

Penelitian ini dilakukan di SMP Raj Yamuna khususnya pada siswa kelas VII A dengan jumlah siswa 18 orang. Waktu penelitian dilakukan kurang lebih selama 8 bulan. Dimulai dari bulan Januari. Pada bulan Januari, perancangan atau pembuatan proposal penelitian. Setelah itu pada bulan Februari dilakukan pengujian bahan atau materi sebagai pedoman dalam menganalisis data yang di kaji. Selesai ujian proposal segera dilakukan perbaikan dari kesalahan dalam penyusunan bahan atau materi. Kemudian pada bulan Maret hingga Mei dilakukan penelitian sesuai dengan proposal penelitian yang telah di ajukan. Data yang sudah terkumpul kemudian dianalisis sesuai dengan materi yang telah disampaikan sebelumnya.

Instrumen yang digunakan dalam mengumpulkan data adalah instrument text dan tes. Di mana instrument text dijadikan bahan atau permasalahan yang akan dipecahkan oleh peserta didik. Sedangkan instrument tes berupa tes esai yang mengharuskan peserta didik untuk memberikan jawaban dengan menguraikan jawaban tersebut tanpa ada pilihan jawaban lain. Jawaban tersebut hasil diskusi dari kelompok karena dalam penelitian ini menggunakan 
metode pembelajaran kooperatif tipe NHT (Numbered Head Together).

Untuk metode yang digunakan dalam mengumpulkan data adalah metode observasi dan metode dokumentasi. Metode observasi digunakan sebagai pengamatan yang langsung dilakukan pada subjek dan objek yang dituju. Dalam penelitian ini observasi dilakukan pada siswa kelas VII A di SMP Raj Yamuna. Sedangkan metode dokumentasi digunakan sebagai rekaman atau pelengkap dokumen yang dibutuhkan saat penelitian. Dengan hasil rekaman tersebut dapat melihat bagaimana respon yang ditunjukkan oleh peserta didik.

Metode dan teknik penyajian analisis data yang digunakan sebagai berikut : Metode yang digunakan dalam analisis data adalah metode analisis dan metode deskriptif. Metode analisis digunakan dalam proses penilaian pembelajaran. Sedangkan Metode deskriptif digunakan untuk memaparkan hasil analisis data yang diperoleh. Teknik dalam penyajian data yang digunakan adalah teknik informal dan formal. Penyajian formal adalah perumusan dengan menggunakan tanda atau lambang- lambang, sedangkan yang dimaksud dengan penyajian Informal adalah perumusan dengan kata-kata biasa.

\section{HASIL DAN PEMBAHASAN}

Penelitian yang dilakukan oleh penulis adalah Penelitian Tindakan Kelas (PTK). Menurut Arikunto, dkk
(2016:4) mengatakan bahwa Penelitian Tindakan Kelas (PTK) adalah penelitian yag memaparkan terjadinya sebabakibat dari perlakuan, sekaligus memaparkan apa saja yang terjadi ketika perlakuan diberikan, dan memaparkan seluruh proses sejak awal pemberian perlakuan sampai dampak dari perlakuan yang diberikan kepada subjek tindakan. Penelitian tindakan kelas adalah suatu proses pengkajian masalah pembelajaran di dalam kelas melalui refleksi diri dalam upaya untuk memecahkan masalah dengan cara melakukan berbagai tindakan yang telah direncanakan dalam situasi nyata serta menganalisis setiap pengaruh akibat perlakuan tersebut.

Setiap siklus dilakukan empat kegiatan pokok yakni perencanaan, pelaksanaan, pengamatan dan refleksi. Pada tahap perencanaan ini peneliti menyusun perangkat pembelajaran yang terdiri atas silabus, rencana pelaksanaan pembelajaran (RPP), lembar kerja siswa (LKS), menyusun tes hasil belajar, ulangan harian (UH), pekerjaan rumah (PR), dan membuat lembar pengamatan aktivitas guru dan siswa. Pelaksanaan tindakan dalam hal ini adalah praktik pembelajaran nyata berdasarkan rencana tindakan yang telah disusun sebelumnya. Walapun dapat berubah sesuai dengan kondisi di lapangan, walaupun tindakan ini tetap ditujukan untuk memperbaiki keadaan atau proses dan hasil pembelajaran. Pengamatan ini perlu dilakukan untuk mendapatkan data yang lebih akurat mengenai pelaksanaan 
tindakan dalam setap siklus. Hasil pengamatan ini akan dijadikan pedoman untuk memperbaiki tindakan selanjutnya. Atas dasar pengamatan yang telah dilakukan, selanjutnya dilakukan evaluasi untuk mengetahui seberapa besar keberhasilan yang dilakukan ini. Evaluasi akan dilakukan pada akhir pembelajaran. Refleksi dilakukan dengan melihat hasil pengamatan aktivitas belajar (Santika, 2021b). Kemudian dilanjutkan dengan merefleksi tindakan yang telah dilakukan, merangkum kendala-kendala yang ditemui selama tindakan, memikirkan peluang dan rencana yang dilakukan untuk perbaikan pada siklus selanjutnya.

$$
\text { Sebelum dilakukannya }
$$
tindakan siklus I, Tindakan Pra Siklus perlu dilakukan terlebih dahulu. Tindakan Pra Siklus adalah tindakan untuk mengetahui tingkat kemampuan peserta didik sebelum melakukan siklus penelitian. Tindakan Pra Siklus dilaksanakan pada saat melakukan observasi awal yaitu pada siswa kelas VII A SMP Raj Yamuna School. Berdasarkan hasil penelitian peserta didik harus dapat menempuh nilai di atas KKM yaitu dengan nilai 75. Setelah melakukan tes pada tindakan pra siklus persentase peserta didik yang berada di bawah dan di atas KKM dengan perbandingan $67 \%$ peserta didik memiliki skor di bawah KKM dan 33\% peserta didik memiliki skor di atas KKM. Dengan demikian guru harus mencari cara untuk meningkatkan kemampuan peserta didik dalam materi Teks Cerita Fantasi sehingga peserta didik dapat memiliki nilai di atas KKM.

Setelah mengetahui hasil tindakan pra siklus dilanjutkan pada tindakan siklus I. Pada tindakan siklus I sesuai dengan siklus penelitian yaitu perencanaan, pelaksanaan, pengamatan dan refleksi. Berdasarkan hasil penelitian, hasil penilaian yang telah diuraikan peserta didik yang mendapatkan nilai di atas KKM 44\% sedangkan peserta didik yang mendapatkan nilai di bawah KKM 56\%. Banyak aspek yang perlu diperbaiki dan ditingkatkan untuk kelancaran dalam proses pembelajaran. Dalam tindakan pra siklus banyak peserta didik belum mencapai tingkat ketuntasan. Hal tersebut dapat dilihat dari hasil penilaian yang dilakukan setelah memberikan beberapa soal dalam tindakan pra siklus. Karena tindakan pra siklus merupakan tindakan yang dilakukan sebelum memulai proses pembelajaran guna untuk mengetahui seberapa kemampuan peserta didik sehingga dilakukan penilaian dengan tindakan siklus I.

Dalam siklus I tidak jauh berbeda dengan tindakan pra siklus, hanya 7 orang peserta didik yang tuntas dalam proses pembelajaran teks cerita fantasi. Peserta didik yang belum tuntas tersebut perlu dilakukan penanganan agar dapat mencapai tingkat ketuntasan yang diharapkan. Selain itu setelah dilakukan pengamatan dalam proses pembelajaran. Hanya beberapa peserta didik yang aktif dalam kegiatan 
pembelajaran.

Dalam aspek keberanian mengemukakan pendapat hanya beberapa peserta didik yang berani dalam mengemukakan pendapat didepan kelas. Dalam aspek keaktifan/peran serta peserta didik lebih mengandalkan temannya terutama teman yang berani dalam mengemukakan pendapat didepan kelas. Aspek menghargai pendapat orang lain, dalam aspek ini peserta didik lebih menghargai pendapat yang disampaikan oleh temannya kemudian langsung mereka setujui pendapat tersebut. Tidak heran dalam aspek ini lebih banyak yang mendapatkan skor sempurna. Selanjutnya dalam aspek kerjasama kelompok, dalam aspek ini ada kelompok yang mau bekerja sama dengan baik dan adapula yang tidak mau bekerja sama dengan baik. Dalam hal ini faktor pertemanan yang menjadi pegangan mereka. Di mana jika mereka tidak berteman baik dengan kelompok tersebut mereka tidak mau bekerja sama. Sehingga dalam pembentukan kelompok guru tidak memberikan kesempatan mereka untuk memilih teman, sehingga metode NHT yang digunakan guru sangat berpengaruh dalam pembentukan kelompok. Aspek terakhir adalah aspek memecahkan masalah, dalam aspek ini peserta didik belum mampu menyelesaikan masalah dengan baik. Sehingga pada siklus I ini belum mencapai maksimal harus dilakukan evaluasi kembali. Hasil evaluasi tersebut perlu di tindaklanjuti kembali ke tahap selanjutnya yaitu tindakan penelitian siklus II.

Setelah direfleksi pada tindakan siklus I, dilanjutkan pada tindakan siklus II. Dari skor dan penilaian yang diperoleh peserta didik. Yang mendapatkan nilai diatas dan dibawah KKM dengan perbandingan persentase $89 \%$ di atas KKM dan 11\% di bawah KKM. Berdasarkan hasil pengamatan yang telah dilakukan perbandingan antara siklus I dengan siklus II mengalami peningkatan. Di mana pada siklus I peserta didik pasif hanya menerima atau menghargai pendapat orang lain. Pada siklus II peserta didik berani mengemukakan pendapat dan dapat memecahkan masalah meskipun hanya beberapa peserta didik. Peserta didik yang mampu dan berani dalam menyelesaikan tugas ini adalah peserta didik yang ingin menambah nilainya dalam mata pelajaran teks cerita fantasi.

Tidak jauh berbeda dengan siklus I peserta didik masih belum dapat mengontrol kondisi keramaian daam kelas. Sedangkan untuk pembagian kelompok mereka sudah mulai tanggap dan segera menemukan kelompoknya yang telah dibagikan oleh guru. Sebelumnya pada siklus I keaktifan peserta didik dalam mengerjakan tugas mengapresiasi unsur teks cerita fantasi sangat kurang, tetapi dalam siklus II keaktifan atau peran serta dalam mengerjakan tugas tersebut sangat baik.

Kelima aspek yang menjadi penilaian dalam metode Numbered 
Head Together (NHT) peserta didik kurang dalam aspek memecahkan masalah hanya beberapa peserta didik yang dapat memecahkan masalah dalam mengapresiasikan unsur teks cerita fantasi. Peserta didik yang mampu memecahkan masalah termasuk peserta didik yang fokus untuk menyelesaikan masalah tersebut. Berdasarkan tabel di atas dari tindakan pra siklus hingga siklus II mengalami peningkatan. Di mana peserta didik mampu mengikuti penggunaan dan penerapan dengan menggunakan metode Numbered Head Together (NHT) yang diterapkan oleh guru. Sehingga metode NHT dapat dijadikan metode pembelajaran dalam kelas agar peserta didik tidak merasa bosen dengan metode yang sebelumnya digunakan. Selain hasil observasi yang telah diuraikan, peserta didik pun mengisi sebuah kuesioner sebagai penilaian respon atau tanggapan peserta didik dengan metode Numbered Head Together (NHT) yang digunakan.

\section{SIMPULAN DAN SARAN}

Berdasarkan hasil pembahasan setelah melaksanakan penelitian di SMP Raj Yamuna kelas VII A, maka dapat disimpulkan hasil penelitian sebagai berikut: Metode Numbered Head Together (NHT) dapat meningkatkan kemampuan mengapresiasi karya sastra berdasarkan unsur- unsur yang terkandung dalam teks cerita fantasi khususnya di kelas VII A SMP Raj Yamuna. Berdasarkan hasil penelitian dari tindakan pra siklus, tindakan siklus
I hingga tindakan siklus II mengalami persentase yang meningkat melihat dari hasil kemampuan peserta didik selama proses pembelajaran. Sehingga metode NHT dapat diterapkan dalam proses pembelajaran di dalam kelas. Dalam mengapresiasikan teks cerita fantasi pada pembelajaran ini lebih memfokuskan bagaimana cara peserta didik mampu memahami teks cerita fantasi melalui unsur yang terkandung dalam teks cerita fantasi tersebut.

Respon peserta didik kelas VII A SMP Raj Yamuna dalam pembelajaran teks cerita fantasi dengan menggunakan metode Numbered Head Together (NHT). Untuk menilai respon peserta didik dalam proses pembelajaran dilakukan dengan memberikan kuesioner dan membuat lembar observasi keaktifan peserta didik. Berdasarkan hasil penelitian peserta didik di kelas VII A memberikan respon yang sangat baik dengan metode NHT ini.

Berdasarkan hasil simpulan diatas, berikut beberapa saran yang dapat diberikan sebagai berikut : Penelitian ini dapat dijadikan pertimbangan bagi guru untuk menggunakan cerita fantasi sebagai bahan apresiasi cerita dalam pembelajaran Bahasa Indonesia. Peneliti selanjutnya, disarankan untuk melakukan penelitian sejenis secara rinci dan mendalam supaya pembelajaran sejenis dapat dideskripsikan secara detail. 


\section{DAFTAR PUSTAKA}

Artati, Budi dan Uti Darmawati, 2016. Bahasa Indonesia SMP kelas VII Semester 1. Klaten: Intan Pariwara.

Berta, M. O., \& Swarniti, N. W. (2020). IMPROVING THE STUDENTS' VOCABULARY MASTERY THROUGH WORD SQUARE GAME AT THE EIGHTH GRADE OF SMP DWIJENDRA DENPASAR IN THE ACADEMIC YEAR 2019/2020. Widyasrama, 30(2), 18-25.

Fajria, Najmi. 2017. "Pelaksanaan Pembelajaran Teks Cerita Fantasi di kelas VII F SMP Negeri

8 Yogyakarta” (Skripsi), Yogyakarta: Program Studi Pendidikan Bahasa dan Sastra Indonesia. Fakultas Bahasa dan Seni Universitas Negeri Yogyakarta.

Lede, D. A. S., \& Swarniti, N. W. (2020). IMPROVING THE STUDENTS' VOCABULARY MASTERY BY USING TREE DIAGRAM ON THE EIGHTH GRADE STUDENTS' OF SMP DWIJENDRA IN THE ACADEMIC YEAR 2019/2020. Widyasrama, 30(2), 51-57.

Rahayu, Neneng. 2017. "Penggunaan Komik sebagai Media Pembelajaran untuk meningkatkan Kemampuan Mengapresiasikan Cerita Fantasi pada peserta didik kelas VII A SMP Negeri

3 Subang tahun Pelajaran 20162017” (Jurnal Ilmiah), Subang: Guru SMP Negeri 3 Subang FKIP Universitas Subang.

Krisno, Agus. 2016. Sintaks 45 Metode Pembelajaran dalam Student Centered Learning (SCL). Malang: Universitas Muhammadiyah.

Kurniasih, Imas dan Berlin Sani. 2017. Ragam Pengembangan Model Pembelajaran Untuk Peningkatan Profesionalitas Guru. Jakarta: Kata Pena.

Nafisah, Durratun dkk. 2012. "Karakteristik Cerita Fantasi Anak Indonesia Periode 20002010” (Skripsi), Malang: Program Studi Pendidikan
Bahasa, Sastra Indonesia dan Daerah Universitas Negeri Malang.

Nofia, Elin dkk. 2018. " Tokoh dan Penokohan dalam Teks Cerita Fantasi karya siswa kelas VII SMP Negeri 1 Payakumbuh" (Skripsi), Padang: Program Studi Pendidikan Bahasa dan Sastra Indonesia FBS Universitas Negeri Padang.

Rizkiah, Finny dkk. 2018. "Struktur dan Kebahasaan Teks Cerita Fantasi karya siswa kelas VII SMP Pembangunan Laboratorium" (Jurnal), Padang: Program Studi Pendidikan Bahasa dan Sastra Indonesia FBS Universitas Negeri Padang.

Santika, I. G. N. (2017). Kepala Sekolah Dalam Konsep Kepemimpinan Pendidikan: Suatu Kajian Teoritis. Widya Accarya, 7(1). http://103.39.12.42/index.php/wi dyaaccarya/article/view/898

Santika, I. G. N. (2018). Strategi Meningkatkan Kualitas SDM Masyarakat Desa Padangsambian Kaja Melalui Pendidikan Karakter Berbasiskan Kepedulian Lingkungan Untuk Membebaskannya Dari Bencana Banjir. Widya Accarya, 9(1).

Santika, I. G. N. (2021a). Grand Desain Kebijakan Strategis Pemerintah Dalam Bidang Pendidikan Untuk Menghadapi Revolusi Industri 4.0. Jurnal Education and Development, 9(2), 369-377.

Santika, I. G. N. (2021b). Pendidikan Kewarganegaraan (Studi Komparatif Konstitusi Dengan UUD 1945). Lakeisha.

Santika, I. G. N. (2021c). Tinjauan Historis Terhadap Keppres No. 24 Tahun 2016 Tentang Hari Lahir Pancasila. Vyavahara Duta, XVI(2), 5-24. https://doi.org/http://dx.doi.org/1 0.25078/vd.v16i2.2384

Suryani, Wadu. dan Adnyana, I Ketut Suar. 2018. Tindak Tutur Direktif 
dalam Novel Harmony dalam

Tanda Tanya (?) Karya Melvi

Yendra \& Andriyati Stilistika

Volume 9, Nomor 2, Mei 2021.

Swarniti, N. W. (2020). Fenomena Morfologi pada Berita-Berita di CNN Indonesia Mengenai Covid19: Kajian Linguistik. In COVID-19 Perspektif Susastra dan Filsafat (p. 93). Yayasan Kita Menulis. 